\title{
EFFECTS OF SUSPENDED SOLIDS AND DISSOLVED ORGANIC CARBON ON NICKEL TOXICITY
}

\author{
Christina E. Cloran, $* \dagger$ G. Allen Burton, $\dagger \ddagger$ Chad R. Hammerschmidt,$\dagger$ W. Keith Taulbee $\ddagger$ \\ Kevin W. Custer, $\dagger$ and Katlin L. Bowman $\dagger$ \\ $\dagger$ †epartment of Earth \& Environmental Sciences, Wright State University, 3640 Colonel Glenn Hwy., Dayton, Ohio 45435, USA \\ $\ddagger$ School of Natural Resources and Environment, University of Michigan, Ann Arbor, Michigan 48109, USA
}

(Submitted 10 November 2009; Returned for Revision 12 January 2010; Accepted 24 February 2010)

\begin{abstract}
Nickel (Ni) is a common and potentially toxic heavy metal in many fluvial ecosystems. We examined the potentially competitive and complementary roles of suspended sediment and a dissolved organic ligand, humate, in affecting the partitioning and toxicity of Ni to a model organism, Daphnia magna, in both batch and stream-recirculating flume (SRF) tests. Sediments included a finegrained deposit, montmorillonite, and kaolinite. Survival of D. magna was unaffected by the range of suspended solids used in the present study (8-249 mg/L). However, exposure to suspended solids that were amended with $\mathrm{Ni}$ had a deleterious effect on test organism survival, which is attributed to partitioning of $\mathrm{Ni}$ into the aqueous phase. At comparable levels of dissolved $\mathrm{Ni}$, survival of $D$. magna was reduced in tests with $\mathrm{Ni}$-amended suspended solids compared to Ni-only aqueous exposures, suggesting potentiation between these two aquatic contaminants. Addition of humate attenuated toxicity to D. magna in both Ni-only and Ni-amended suspended sediment exposures. These results indicate that organic ligands and suspended solids have important functions in affecting the bioavailability and toxicity of $\mathrm{Ni}$ to aquatic organisms and should be incorporated into predictive models to protect ecosystem quality. Environ. Toxicol. Chem. 2010;29:1781-1787. (C) 2010 SETAC
\end{abstract}

Keywords-Nickel Clay Humate Sediment Daphnia magna

\section{INTRODUCTION}

Nickel $(\mathrm{Ni})$ is abundant in the Earth's crust [1], and with many industrial and commercial uses, contamination of surface waters is ubiquitous in human-dominated watersheds [2-3]. The bioavailability and toxicity of $\mathrm{Ni}$ in aquatic systems ([4-6]; http://www.atsdr.cdc.gov/toxprofiles/tp15-c6.pdf) are often determined by sorption to solid phases [7] and complexation with dissolved ligands, particularly dissolved organic matter (DOM) $[8,9]$. These reactions affect the amount of total Ni in solution and reduce the fraction as free ionic $\mathrm{Ni}\left(\mathrm{Ni}^{2+}\right)$, which, for many organisms, is presumed to be the toxic metal species [10-16]. Sorption of free ionic and complexed Ni species to solid phases occurs through processes of ligand binding and hydrophobic [17] and electrostatic attraction [18]. This results in Ni being associated with a variety of natural solid phases, including, for example, organic matter, metal oxyhydroxides, and clays $[19,20]$. The affinity of aqueous $\mathrm{Ni}$ for particles is often expressed as the distribution coefficient $\left(K_{\mathrm{d}}, \mathrm{L} / \mathrm{kg}\right)$, which is the ratio of measured concentration on the solid phase to that in the enveloping aqueous phase [21].

Suspended solids (SS) can reduce dissolved metal concentrations and thereby potentially ameliorate toxicity, but also may adversely impact aquatic biota. Indeed, SS, rather than metals or nutrients, have been identified as the most common cause of river and stream impairment [6,22]. Hence, while extreme loadings of suspended sediments can be toxic to aquatic biota, moderate levels of SS, through their sorptive affinity for dissolved metals, may attenuate bioavailability and toxicity of co-occurring metal contaminants such as $\mathrm{Ni}$.

\footnotetext{
* To whom correspondence may be addressed (christina@cloran.com).

Published online 23 April 2010 in Wiley InterScience (www.interscience.wiley.com).
}

Humic substances are ubiquitous components of DOM in natural waters and have important roles in both mitigating metal toxicity to aquatic organisms $[9,23]$ and affecting partitioning of metals between aqueous and solid phases. Humic substances contain a range of chelating functional groups (carboxyl, thiol) that serve to reduce free metal ion concentration and bioavailability. Moreover, the rate and extent of metal adsorption to particles is dependent on the concentration and quality of DOM $[8,9,24,25]$, which competes with solidphase ligands for metals. Adsorption of metal ions to surfaces of clay minerals, for example, decreases in the presence of dissolved organic ligands [26]. Toxicity is defined as accumulation of metal at the biotic ligand at or above a critical threshold concentration [27].

Here we examine the potentially competitive and complementary roles of suspended sediment and humic substances in affecting the partitioning and toxicity of $\mathrm{Ni}$ to a model test organism, Daphnia magna. In a recent literature search, Meyer et al. [10] found no Ni toxicity tests in which only SS was varied. Further, there is limited information on the effect of DOM on Ni toxicity $[12,14]$. With controlled, multivariate laboratory tests, we attempt to isolate natural (suspended sediment) and anthropogenic (nickel) stressors and predict their relative importance to aquatic biota.

\section{MATERIALS AND METHODS}

The effects of SS and a humic substance on Ni partitioning and toxicity to D. magna were investigated with a series of laboratory tests conducted with both batch and streamrecirculating flume (SRF) approaches. These experiments included examinations of single stressors (Ni only), different suspended particle types (natural sediment and two types of pure clays) and concentrations, with and without added $\mathrm{Ni}$, and 
combinations of multiple variables (aqueous $\mathrm{Ni}+$ suspended particles + humate).

\section{Test sediment}

The effect of suspended sediments on partitioning and toxicity of Ni to D. magna was examined with a natural sediment and two clays, montmorillonite and kaolinite. Natural sediment was obtained following U.S. Environmental Protection Agency (U.S. EPA) protocols $[28,29]$ from Warden Ditch Canal located in Clark County, Ohio, USA. This fine-grained (75\% clay) and relatively high-organic content ( $7.7 \%$ total organic carbon) deposit had the following physicochemical characteristics (dry wt basis): total $\mathrm{Ni}=18 \mathrm{mg} / \mathrm{kg}$, simultaneously extracted metal (SEM) $\mathrm{Ni}=6 \mathrm{mg} / \mathrm{kg}$, acid volatile sulfides $(\mathrm{AVS})=2,500 \mathrm{mg} / \mathrm{kg}$, total iron $=21 \mathrm{~g} / \mathrm{kg}$, total manganese $=410 \mathrm{mg} / \mathrm{kg}$, SEM $/$ AVS molar ratio $=0.001$, water content $=76.4 \%$, and pore water dissolved organic carbon $(\mathrm{DOC})=5.2 \mathrm{mg} / \mathrm{L}$. Kaolinite (analytical grade, Fluka) was selected because it is a simple type of clay and a common, naturally occurring colloid [30]. In contrast, montmorillonite (KSF, analytical grade, Acros Organics) is a 2:1 layer mineral (smectite family) with a surface area five times greater than that of kaolinite. Montmorillonite has high cation-exchange capacity (CEC) due to substitution of the main cations with those having lower valence [26], which allows the mineral to bind not only free cations such as Ni but also organically complexed cations [30].

Warden Ditch sediment and the two clays were amended with $\mathrm{Ni}$ to a nominal concentration of $5,000 \mathrm{mg} / \mathrm{kg}$ dry weight. Concentrated stock solutions of $\mathrm{Ni}$ were prepared by dissolving $\mathrm{NiCl}_{2} \cdot 6 \mathrm{H}_{2} \mathrm{O}$ in reagent-grade water (nominal resistivity, $>15 \mathrm{M} \Omega-\mathrm{cm}$ ). Nickel stock solution was added to Warden Ditch deposits and aqueous slurries of pure kaolinite and montmorillonite in 4-L plastic bottles, homogenized for $2 \mathrm{~h}$ on a roller mill, and allowed to equilibrate for $56 \mathrm{~d}$ in the dark at $4^{\circ} \mathrm{C}$ [29]. Prior to the start of each test, containers of sediment and clay were rolled for another $2 \mathrm{~h}$ to incorporate any interstitial water that separated during storage. Nickel-spiked sediment/clay was added to test containers immediately after mixing. Sediment suspensions having $12.5,25$, and 50 nephelometric turbidity units (NTU) were prepared for each of the three Ni-amended solids and maintained in each beaker by magnetic stirring with a Teflon-coated bar (375 rpm). Monitoring of turbidity levels throughout the course of the experiments indicated that the suspensions were uniform.

\section{Test conditions}

Batch tests were conducted in 4-L glass beakers filled with culture water that was stirred magnetically. Stream-recirculating flume tests were conducted inside a fiberglass flume (Frigid Units ${ }^{\circledR}$ ) in the laboratory. Water hardness in both batch and SRF experiments was prepared to replicate the 50th percentile of observed hardness in European surface waters $(99 \mathrm{mg} / \mathrm{L}$ as $\mathrm{CaCO}_{3}$ ). Test water was made by dissolving salts in reagentgrade water (adapted from Smith et al. [31]). Measured hardness of test water was $100 \pm 5 \mathrm{mg} / \mathrm{L}$ as $\mathrm{CaCO}_{3}$.

Daphnia magna test organisms were obtained from a culture in the Burton Laboratory at Wright State University, Dayton, Ohio, USA. These organisms were cultured from parental organisms, provided by the U.S. EPA, according to standard protocols in synthetic hard water $\left(\approx 160-180 \mathrm{mg} / \mathrm{L}\right.$ as $\left.\mathrm{CaCO}_{3}\right)$ [31]. Daphnia magna used for laboratory tests were neonates $(<24 \mathrm{~h}$ old, broods $2-5)$. Mortality was the acute endpoint; survival was determined by counting the number of living versus dead organisms (evaluated as immobility) at the end of each 48-h test.
In both batch and SRF tests D. magna were exposed to Ni and other stressors inside cylindrical chambers constructed of transparent cellulose acetate butyrate (10 D. magna neonates per chamber). Each chamber $(7.0 \mathrm{~cm}$ outer diameter (OD), $6.7 \mathrm{~cm}$ inner diameter (ID), $13 \mathrm{~cm}$ long) had two rectangular windows $(4 \times 8 \mathrm{~cm})$, covered with $250 \mu \mathrm{m}$ nylon mesh, on opposite sides of the tube, and was closed on both ends with polyethylene caps [32]. Chambers were either suspended vertically inside 4-L glass beakers during batch experiments (one chamber per beaker) or secured horizontally to a plastic frame during flume tests (Cloran CE, 2008, Master's thesis, Wright State University, Dayton, OH, USA). Batch and SRF tests were conducted with a photoperiod of $16: 8 \mathrm{~h}$ light:dark at $1.464 \mathrm{~W} \mathrm{~m}^{-2}$ from a halogen lamp, as recommended by the U.S. EPA [28]. Organisms were deprived of food for the duration of the experiment.

\section{Batch tests}

Dynamic, nonrenewal, short-term batch tests were used to investigate $\mathrm{Ni}$ partitioning and the independent and interactive effects of multiple treatment variables on toxicity to D. magna. Levels of Ni and humate (humic acid, Sigma-Aldrich), a model $\mathrm{Ni}$-complexing ligand, were varied in some batch tests, often in combination with each other and varying types (Warden Ditch sediment, montmorillonite, kaolinite) and amounts of suspended material. For batch tests (31 total), four replicates of each of the following treatments were conducted concurrently: Aqueous Ni only: Total dissolved Ni (measured) of 210, 350, $750,1,500,3,100$, and $6,200 \mu \mathrm{g} / \mathrm{L}$; Humate only: Humate concentrations of $1,7,18,48$, and $80 \mathrm{mg} \mathrm{C} / \mathrm{L}$ (measured) were selected to reflect the natural range of DOC in most freshwater systems $(\approx 1-15 \mathrm{mg} \mathrm{C} / \mathrm{L})$, although levels can vary seasonally by $10^{2}$-fold in some rivers $[33,34]$; Humate + aqueous $\mathrm{Ni}$ : Humate at $1,7,18,48,80 \mathrm{mg} \mathrm{C} / \mathrm{L}$ in combination with the LC75 of $\mathrm{Ni}$ (lethal concentration of $\mathrm{Ni}$ for $75 \%$ of test organisms), as determined from Ni only tests; Suspended sediment only: Warden Ditch sediment, montmorillonite, and kaolinite at $50 \mathrm{NTU}$; Ni-amended suspended sediment only: Warden Ditch sediment $(5,300 \mathrm{mg} \mathrm{Ni} / \mathrm{kg}$ dry wt), montmorillonite $(4,100 \mathrm{mg} / \mathrm{kg})$, and kaolinite $(3,600 \mathrm{mg} / \mathrm{kg})$ at each of three turbidity levels (12.5, 25, and $50 \mathrm{NTU})$; Ni-amended suspended sediment + humate: Humate concentration of $7 \mathrm{mg} \mathrm{C} / \mathrm{L}$ with either Ni-amended Warden Ditch sediment or montmorillonite clay at about 50 NTU; and control: Test water with no added $\mathrm{Ni}$, suspended sediment, or humate.

Physicochemical parameters, including temperature, $\mathrm{pH}$, dissolved oxygen, and conductivity, were measured electrochemically in each beaker at the start and end of each 48-h test. Hardness and alkalinity were determined with standard methods [35]. Physicochemical water quality variables were similar in all batch and SRF experiments (Table 1). Water samples also were collected from each chamber for analysis of total $\mathrm{Ni}$ and DOC in filtered water $(0.4 \mu \mathrm{m}$, polycarbonate filter $)$ and total $\mathrm{Ni}$ in unfiltered aliquots. Water for $\mathrm{Ni}$ analysis was sampled at the start and end of each 48-h test, with the exception of Ni-only treatments, which were sampled only at the start. Standard methods were used to determine total suspended solids (TSS) from a separate aliquot of test water [35]. Water for determination of Ni was acidified to $1 \%$ with $\mathrm{HNO}_{3}$ (J.T. Baker InstraAnalyzed ${ }^{\mathbb{R}}$ ) and water for DOC analysis was acidified to $1 \%$ with $\mathrm{HCl}$ and stored refrigerated.

SRF tests

Daphnia magna were exposed to $\mathrm{Ni}$ in chambers inside a recirculating stream channel (inner dimensions, $2.9 \mathrm{~m}$ 
Table 1. Mean ( \pm 1 standard deviation of the mean) physicochemical characteristics of test water for 31 batch and three stream-recirculating flume (SRF) experiments

\begin{tabular}{|c|c|c|c|c|c|c|}
\hline Test type & $\mathrm{pH}$ & $\begin{array}{c}\text { Temperature } \\
\left({ }^{\circ} \mathrm{C}\right)\end{array}$ & $\begin{array}{l}\text { Dissolved } \\
\mathrm{O}_{2}(\mathrm{mg} / \mathrm{L})\end{array}$ & $\begin{array}{c}\text { Specific } \\
\text { conductance }(\mu \mathrm{S} / \mathrm{cm})\end{array}$ & $\begin{array}{c}\text { Hardness } \\
\left(\mathrm{mg} / \mathrm{L} \text { as } \mathrm{CaCO}_{3}\right)\end{array}$ & $\begin{array}{c}\text { Alkalinity } \\
\left(\mathrm{mg} / \mathrm{L} \text { as } \mathrm{CaCO}_{3}\right)\end{array}$ \\
\hline Batch & $7.89 \pm 0.04$ & $21.5 \pm 0.4$ & $7.87 \pm 0.10$ & $440 \pm 5$ & $100 \pm 2$ & $94 \pm 2$ \\
\hline SRF & $8.23 \pm 0.05$ & $22.2 \pm 0.4$ & $8.98 \pm 0.09$ & $534 \pm 6$ & $102 \pm 3$ & $96 \pm 3$ \\
\hline
\end{tabular}

long $\times 0.3 \mathrm{~m}$ wide $\times 0.3 \mathrm{~m}$ deep). Water flow through the channel had a uniform velocity of approximately $12 \mathrm{~cm} / \mathrm{s}$. Slurries of either Ni-amended Warden Ditch sediment or Ni-amended clay were added to the head of the SRF channel. Moderate turbidity persisted for the duration of the 48-h tests (Warden Ditch $=32$ NTU; montmorillonite $=23$ NTU; kaolinite $=38 \quad$ NTU), although a fine layer of clay/silt was deposited in the channel and inside the exposure chambers. Four exposure chambers housing D. magna, in addition to four empty chambers used for chemical sampling, were arranged randomly midway along the channel. Chamber windows were oriented toward the side of the channel. Temperature, $\mathrm{pH}$, dissolved oxygen, conductivity, and turbidity were monitored continuously with a sonde. Temperature and water level in the flume were constant over the course of the experiments. Water was sampled for Ni determination at $0,12,24$, and $48 \mathrm{~h}$ and for DOC analysis at $24 \mathrm{~h}$. Water was withdrawn from each of the four empty chambers through sampling ports on the downstream caps and equal-volume aliquots were composited. Controls for these tests consisted of chambers inside beakers in a controlled water bath.

\section{Sample analysis}

Total Ni was measured in water and sediment/clay samples. Nickel in filtered and unfiltered water samples was determined by inductively coupled plasma mass spectrometry (ICPMS) according to U.S. EPA Method 6020A [36]. The amount of Ni adsorbed to particles in batch and SRF tests was calculated as the difference between measured concentrations in filtered and unfiltered water and normalized to the mass of TSS determined from a separate aliquot [36]. Distribution coefficients $\left(K_{\mathrm{d}}, \mathrm{L} / \mathrm{kg}\right)$ were calculated from filtered and particle-associated $\mathrm{Ni}$ concentrations. Sediments were analyzed by flame atomic absorption spectrophotometry [37] after microwave digestion with $16 \mathrm{M} \mathrm{HNO}_{3}$ [38]. All $\mathrm{Ni}$ analyses were calibrated with an aqueous standard traceable to the U.S. National Institute of the Standards and Technology and calibration curves had coefficients of determination $>0.997$. Analytical reproducibility averaged $3.4 \%$ relative standard deviation (RSD) for replicate analyses of water $(n=29)$ and $1.6 \%$ RSD for replicate digestions of solids $(n=3)$. All Ni analyses were well above our detection limits of approximately $0.1 \mu \mathrm{g} / \mathrm{L}$ for water and about $0.1 \mathrm{mg} / \mathrm{kg}$ for a $0.3-\mathrm{g}$ aliquot of freeze-dried sediment.

The DOC was determined with a total organic carbon analyzer following U.S. EPA Method 9060A [39]. Total organic carbon of the sediment and two clays was measured with an elemental analyzer (Carlo Erba NA1500 C/H/N Analyzer; micro-Dumas combustion assay) at the University of Georgia Institute of Ecology Stable Isotope/Soil Biology Laboratory (Athens, GA, USA).

Particle size distribution of Warden Ditch sediment was assayed with methods of Kettler et al. [40]. Silt was defined as particles $<62 \mu \mathrm{m}$ in diameter and clay $<4 \mu \mathrm{m}$.

\section{Statistical analysis}

Statistical analyses were performed with $\operatorname{SAS}^{\circledR}$ 9.1.3. All model assumptions were tested and satisfied by the method that was ultimately used. Statistical tests and calculations are based on measured Ni concentrations. The Ni LC75 was determined with ToxCalc ${ }^{\mathrm{TM}}$ (Tidepool Scientific Software).

\section{RESULTS}

Survival of control organisms for all experiments was $100 \%$. In response to measured $\mathrm{Ni}$ concentrations of $210,350,750$, $1,500,3,100$, and $6,200 \mu \mathrm{g} / \mathrm{L}$ in Ni-only batch experiments, survival of D. magna was $100,83,65,53,15$, and $0 \%$, respectively (Fig. 1). From these results, the Ni LC75 was calculated to be $2,150 \mu \mathrm{g} / \mathrm{L}$ for D. magna.

Survival of $D$. magna was unaffected by humate at exposures less than $18 \mathrm{mg} \mathrm{C} / \mathrm{L}$ in batch experiments, although exposures of 48 and $80 \mathrm{mg} \mathrm{C} / \mathrm{L}$ decreased survival by approximately 15 and $55 \%$, respectively, relative to lower humate levels (Fig. 2). The potential mitigating effect of humate on Ni toxicity to $D$. magna was investigated in tests that included this range of humate and aqueous $\mathrm{Ni}$ added at the $\operatorname{LC75}(2,150 \mu \mathrm{g} / \mathrm{L})$. Relative to expected survival based on $\mathrm{Ni}$ exposure alone (i.e., 25\%), only the $18 \mathrm{mgC} / \mathrm{L}$ humate treatment enabled greater survival and the $80 \mathrm{mgC} / \mathrm{L}$ exposure reduced it (Fig. 2). Observed D. magna survival in the humate $+\mathrm{Ni}$ LC75 experiment is largely consistent with that predicted from single-stressor tests with $\mathrm{Ni}$ and humate alone (Fig. 2), where predicted survival $(\%)=(\%$ survival in humate $) \times(0.25$ survival in $\mathrm{Ni}$ at LC75). Enhanced D. magna survival in the $18 \mathrm{mg} \mathrm{C} / \mathrm{L}$ humate treatment suggests that organic ligands may have ameliorated Ni toxicity.

Suspension of Ni-amended sediment and clay had a deleterious effect on D. magna survival in batch experiments (Fig. 3). For all three Ni-amended solids, survival of $D$. magna decreased as a function of increasing turbidity in batch tests and were consistent with results from SRF experiments with each solid. Substantial differences in D. magna survival existed among types of Ni-contaminated SS, with survival of organisms exposed to montmorillonite being significantly less than those exposed to equal turbidities of either Warden Ditch sediment

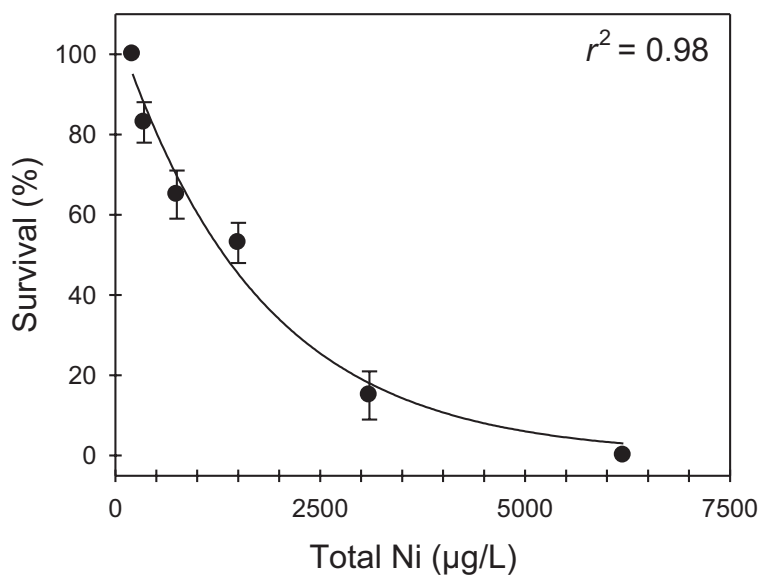

Fig. 1. Survival of D. magna versus total aqueous nickel concentration in Nionly batch experiments. Error bars are one standard deviation of the mean. 


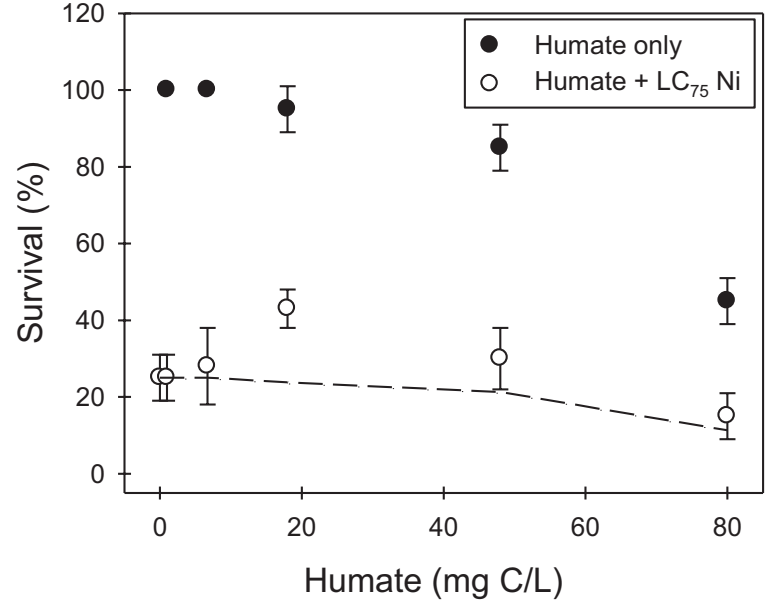

Fig. 2. Survival of D. magna exposed to humate only and humate plus aqueous $\mathrm{Ni}$ at the LC75 (lethal concentration of $\mathrm{Ni}$ for $75 \%$ of test organisms $=2,150 \mu \mathrm{g} / \mathrm{L}$ ). The dashed line represents the additive predicted survival for humate plus $2,150 \mu \mathrm{g} \mathrm{Ni} / \mathrm{L}$ based on combined results from exposures to Ni only and humate only. Error bars are one standard deviation of the mean.

or kaolinite. These results are in marked contrast to batch tests with uncontaminated Warden Ditch sediment, montmorillonite, and kaolinite, which, at $50 \mathrm{NTU}$, had no effect on survival after $48 \mathrm{~h}$.

Apparent toxicological differences among the three types of $\mathrm{Ni}$-amended SS were related, in part, to variations in mass of SS. While turbidity was a linear function of suspended mass for each particle type, light scattering varied substantially among the three solids with, for example, 50 NTU resulting from either $66 \mathrm{mg} / \mathrm{L}$ of Warden Ditch sediment, $249 \mathrm{mg} / \mathrm{L}$ of montmorillonite, or $51 \mathrm{mg} / \mathrm{L}$ of kaolinite. Daphnia magna survival was related inversely to the concentration of Ni-contaminated suspended sediment among all particle types (Fig. 4), and interparticle toxicological differences, suggested by results in Figure 3, were an artifact of using turbidity as a proxy for SS. In contrast, and as noted above, no mortality was observed in tests with uncontaminated SS (no added Ni).

Nickel desorbed from contaminated SS during the experiments. The concentration of dissolved and particle-associated $\mathrm{Ni}$ in solution was a function of the type of suspended solid (Table 2). The affinity of $\mathrm{Ni}$ for the SS, measured as

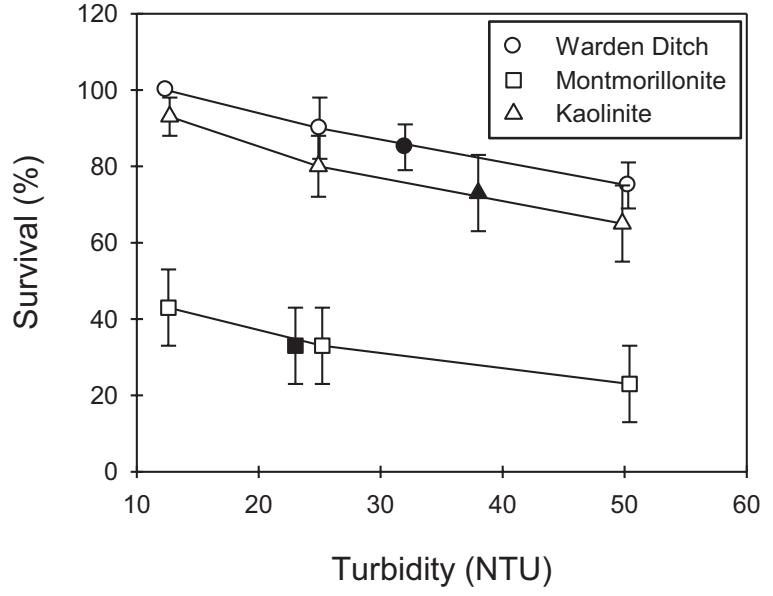

Fig. 3. Survival of D. magna exposed to three Ni-contaminated suspended solids in turbid batch experiments (open symbols) and stream-recirculating flume (SRF) tests (closed symbols). Error bars are one standard deviation of the mean. Units for turbidity are nephelometric turbidity units (NTU).

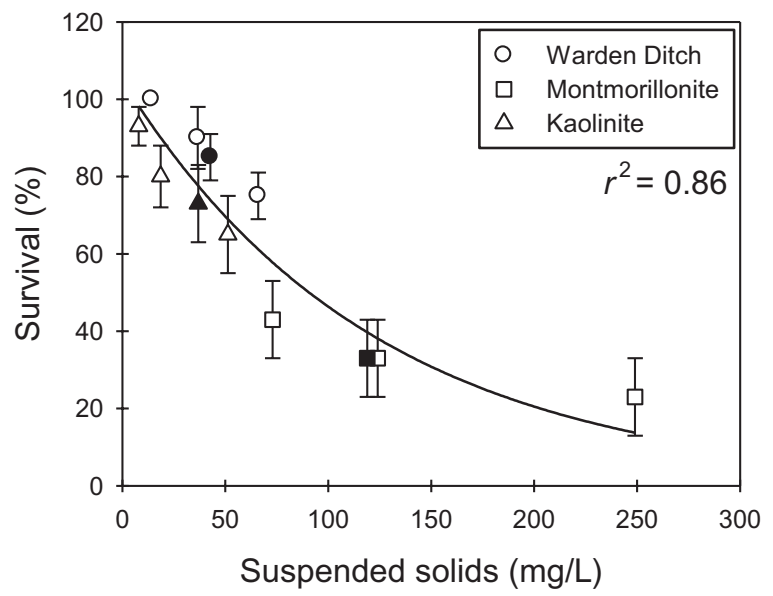

Fig. 4. Survival of D. magna versus concentration of Ni-contaminated suspended solids in turbid batch experiments (open symbols) and streamrecirculating flume (SRF) tests (closed symbols). Error bars are one standard deviation of the mean.

Table 2. Mean measured Ni concentrations and calculated distribution coefficients for tests with suspended solids (SS)

\begin{tabular}{|c|c|c|c|c|c|c|c|}
\hline Arena & Treatment & $\begin{array}{l}\text { Sediment } \\
\text { type }\end{array}$ & $\begin{array}{l}\text { Turbidity } \\
\left(\mathrm{NTU}^{\mathrm{a}}\right)\end{array}$ & $\begin{array}{c}\text { Suspended } \\
\text { sediment }(\mathrm{mg} / \mathrm{L})\end{array}$ & $\begin{array}{l}\text { Dissolved } \\
\mathrm{Ni}(\mu \mathrm{g} / \mathrm{L})\end{array}$ & $\begin{array}{c}\text { Particle } \\
\mathrm{Ni}(\mu \mathrm{g} / \mathrm{L})\end{array}$ & $\begin{array}{r}\log K_{\mathrm{d}} \\
(\mathrm{L} / \mathrm{kg})\end{array}$ \\
\hline \multirow[t]{11}{*}{ Batch (4-L beakers) } & \multirow[t]{9}{*}{$\mathrm{SS}+\mathrm{Ni}$} & \multirow[t]{3}{*}{ Warden Ditch } & 12.4 & 14 & 59 & 18 & 3.85 \\
\hline & & & 25.0 & 37 & 160 & 60 & 3.96 \\
\hline & & & 50.3 & 66 & 310 & 150 & 3.86 \\
\hline & & \multirow[t]{3}{*}{ Montmorillonite } & 12.6 & 73 & 195 & 46 & 3.51 \\
\hline & & & 25.2 & 124 & 270 & 120 & 3.56 \\
\hline & & & 50.4 & 249 & 640 & 300 & 3.28 \\
\hline & & \multirow[t]{3}{*}{ Kaolinite } & 12.7 & 8 & 53 & 0.1 & 2.39 \\
\hline & & & 24.9 & 19 & 110 & 1.0 & 2.72 \\
\hline & & & 49.8 & 51 & 210 & 4.4 & 2.62 \\
\hline & \multirow[t]{2}{*}{$\mathrm{SS}+\mathrm{Ni}+$ humate } & Warden Ditch & 53.5 & 66 & 430 & 170 & 3.77 \\
\hline & & Montmorillonite & 53.9 & 249 & 1200 & 160 & 2.73 \\
\hline \multirow[t]{3}{*}{$\mathrm{SRF}^{\mathrm{b}}$ (480-L flume) } & \multirow[t]{3}{*}{$\mathrm{SS}+\mathrm{Ni}$} & Warden Ditch & 32.1 & 66 & 330 & 190 & 4.13 \\
\hline & & Montmorillonite & 23.0 & 249 & 440 & 490 & 3.63 \\
\hline & & Kaolinite & 38.4 & 51 & 380 & 57 & 3.61 \\
\hline
\end{tabular}

\footnotetext{
${ }^{a}$ Nephelometric turbidity units.
}

${ }^{\mathrm{b}}$ Stream-recirculating flume. 


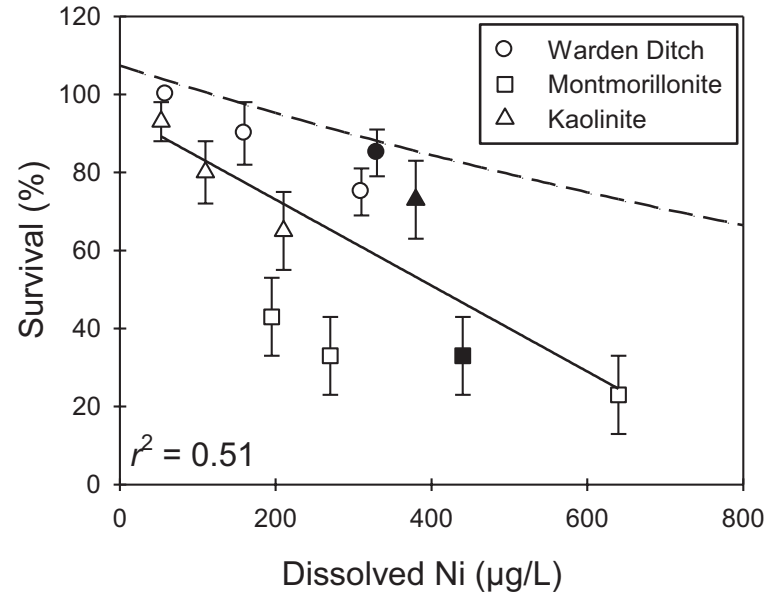

Fig. 5. Survival of $D$. magna related to dissolved $(<0.2 \mu \mathrm{m}) \mathrm{Ni}$ in turbid batch experiments (open symbols) and stream-recirculating flume (SRF) tests (closed symbols). The dashed line is the modeled linear regression curve for survival versus Ni-only exposure from Figure 1. Error bars are one standard deviation of the mean.

the distribution coefficient, was relatively consistent among turbidity treatments for each particle type, with $\mathrm{Ni}$ adsorbing more strongly to Warden Ditch sediment $\left(\log K_{\mathrm{d}}=3.89 \pm 0.06\right)$ than to either montmorillonite $\left(\log K_{\mathrm{d}}=3.45 \pm 0.15\right)$ or kaolinite $\left(\log K_{\mathrm{d}}=2.58 \pm 0.17\right)$ in batch tests. Distribution coefficients were comparable, or increased slightly, in stream recirculating flume experiments with the same solids.

Survival of $D$. magna exposed to suspensions of Ni-contaminated sediment and clay was less than exposure to either dissolved Ni or SS alone. Survival of the organisms decreased with increasing dissolved $\mathrm{Ni}$ (Fig. 5), resulting from desorption from $\mathrm{Ni}$-amended particles, and rates were substantially less than those for either dissolved Ni only (dashed line in Fig. 5) or suspended particles alone (100\%). This suggests that either dissolved Ni and SS acted synergistically to reduce survival of D. magna or that test organisms also may have ingested particleassociated $\mathrm{Ni}$.

Humate (7 mg C/L) was added to 50-NTU suspensions of Niamended Warden Ditch sediment and montmorillonite in batch experiments to examine a potential ameliorative effect on $\mathrm{Ni}$ toxicity. Relative to suspensions without added humate, addition of the ligand increased substantially both the solubility of $\mathrm{Ni}$ and survival of D. magna. Added humate enhanced dissolved Ni by approximately $40 \%$ for Warden Ditch sediment and about $90 \%$ for montmorillonite suspensions (Table 2). Further, addition of humate enabled greater survival of $D$. magna exposed to suspensions of Warden Ditch sediment ( $93 \pm 10 \%$ vs. $75 \pm 6 \%$ without humate) and montmorillonite ( $50 \pm 8 \%$ vs. $23 \pm 10 \%$ without humate).

\section{DISCUSSION}

This research focused on investigating the effects of two environmentally relevant water-quality parameters-type and concentration of suspended particles and humic material - that can be used to refine present predictive models used to protect ecosystem quality. Specifically, moderate levels of uncontaminated SS did not cause mortality to D. magna. Maximum suspended concentrations of Warden Ditch sediment $(66 \mathrm{mg} /$ L), montmorillonite $(249 \mathrm{mg} / \mathrm{L})$, and kaolinite $(51 \mathrm{mg} / \mathrm{L})$ used in our tests are within the range of SS loads determined for 60 major rivers, with most between 20 and 1,000 mg SS/L [41]. Results from our experiments with uncontaminated SS are consistent with those of Weltens et al. [18], for example, who found exposure of D. magna to $500 \mathrm{mg} / \mathrm{L}$ suspensions of clay, sand, and peat resulted in no significant mortality.

Exposure of D. magna to Ni-contaminated suspended particles resulted in significant mortality that increased with the amount of suspended material and concentration of Ni desorbed from the particles. Given that the maximum levels of SS used in these tests were found to be nontoxic to D. magna, these results suggest that either dissolved or dietary $\mathrm{Ni}$, or potentially a combination of the two, was the principal cause of toxicity. The general assumption is that the dissolved fraction of a toxic substance is mainly responsible for toxicity to aquatic organisms [10-16]. However, survival of D. magna exposed to suspensions of Ni-contaminated sediment and clay, and associated desorbed $\mathrm{Ni}$, was substantially less than that of organisms exposed to comparable concentrations of dissolved $\mathrm{Ni}$ alone (Fig. 5). This suggests that aqueous $\mathrm{Ni}$ and $\mathrm{SS}$ have a synergistic effect: the interaction of SS and Ni produced a total effect greater than the sum of individual components. Alternatively, enhanced toxicity in the presence of SS, relative to aqueous $\mathrm{Ni}$ only, also may be attributed ingestion of particle-associated $\mathrm{Ni}$, although we did not examine dietary versus aqueous exposure in the present study [42].

We observed toxicological differences among equal turbidities of a sediment and two clays that were amended with approximately equal amounts of $\mathrm{Ni}$. However, these interparticle differences were not apparent when TSS, as opposed to NTU, was used as a measure of suspended solids. Variability in the light scattering ability of natural particles, especially in dynamic fluvial systems, argues against the future use of NTU as a proxy for SS.

Dissolved organic carbon reduced Ni toxicity. Complexation by DOM can alter metal bioavailability and toxicity to aquatic organisms when the free metal ion is the main bioavailable species (see review by Campbell [43]). Generally, survival of D. magna exposed to Ni-amended Warden Ditch sediment was greater than those exposed to montmorillonite and kaolinite. This may be attributed to either Ni having a relatively greater affinity for Warden Ditch particles (8\% organic content) or complexation of dissolved $\mathrm{Ni}$ by dissolved organic ligands that partitioned from the natural sediment. The latter hypothesis is supported by the observation that, at a comparable level of total dissolved $\mathrm{Ni}$, nickel appeared to be less toxic to D. magna in tests with suspended Warden Ditch sediment. It is also supported by the observation that Ni toxicity was attenuated in tests with added humate, with and without suspended particles, corroborating the research of Arias et al. [44].

In the $\mathrm{Ni}+$ humate batch experiments, increasing concentrations of humate resulted in greater survival of D. magna, despite the toxic Ni concentration (LC75), yet only up to a threshold. With increasing humate, greater rates of survival would be expected because dissolved organic ligand would, in theory, be available to complex $\mathrm{Ni}$ and attenuate toxicity to D. magna. Nevertheless, as levels of humate increased, survival of D. magna was reduced, which may be attributed to humate clinging to their appendages and inhibiting moving/feeding [42]. Results of the characterization of colloidal humic-bound $\mathrm{Ni}$ and uranium in the filtered fraction of contaminated sediment extracts [45] suggested that $\mathrm{Ni}$ was potentially bioavailable because the humic-bound $\mathrm{Ni}$ was present mainly as labile complexes or the free ion. Thus, a combination of the $\mathrm{Ni}$ LC75 and the relatively high humate concentration caused the survival of D. magna to decrease rather than increase at higher levels of humate. 
The median $\log K_{\mathrm{d}}$ of $\mathrm{Ni}$ in oxic surface water is 4.6 (range $3.5-5.7, n=30$ ) [21]. Our experimental distribution coefficients agreed reasonably well with this range. Nickel adsorption to clay surfaces was substantially less than that to the Warden Ditch particles, which might be expected given the affinity of $\mathrm{Ni}$ for organic ligands $[7,8]$. In other research, adsorption of the metal by clay minerals increased with increasing $\mathrm{pH}$ until the metal ions were precipitated as hydroxide minerals above $\mathrm{pH} 8.0[26,46]$. Decreased adsorption at low $\mathrm{pH}$ is due to competition between metal ions and protons for adsorption sites on the clay surface [10]. The active sites on clay surfaces are weakly acidic; these sites gradually are deprotonated at higher $\mathrm{pH}$ resulting in increased adsorption of $\mathrm{Cu}$ (II) and $\mathrm{Ni}$ (II) [46-49]. Conversely, adsorption decreased with increasing ionic strength [10,46-49].

As expected, the adsorption capacity of montmorillonite was greater than that of kaolinite. Bhattacharyya and Gupta $[47,48]$ observed that montmorillonite had a much greater initial rate of Ni uptake than kaolinite, which might be due to the high specific surface area and CEC of montmorillonite as compared to kaolinite. In general, and due to greater Langmuir monolayer capacity, the adsorption capacity of montmorillonite (and modified forms) was enhanced compared to kaolinite (and modified forms) [46-49].

The physicochemistry of the milieu clearly affects the flux and bioavailability of Ni. Beyond its direct connection with bioavailability, Ni fate is dominated by sediment type, solids level, distribution, and speciation. The concentration of SS influences the toxicity of exchangeable Ni. Therefore, SS should be considered as a separate compartment and key factor in risk assessments. Moreover, inclusion of Warden Ditch sediment in the present study illustrates the differences and complexity of natural systems relative to controlled, clay-only exposures. The addition of humate to the exposure condition further shows ligand availability as a factor affecting metal bioavailability in natural systems [49]. The results of the present study suggest that while dissolved $\mathrm{Ni}$ is a good predictor of bioavailability and toxicity, suspended sediment and dissolved organic ligands have important geochemical regulation over partitioning, speciation, and associated toxicity of Ni.

Acknowledgement-Brian Congiu helped with DOC analyses and Beverly Grunden assisted with statistical analyses. Support for the present study was provided, in part, by the Wright State University Research Challenge Program.

\section{REFERENCES}

1. Li Y-H. 2000. A Compendium of Geochemistry. Princeton University, Princeton, NJ, USA.

2. Agency for Toxic Substances and Disease Registry. 2005. Toxicological profile for nickel. U.S. Department of Health and Human Services, Atlanta, GA, USA.

3. Cempel M, Nikel G. 2006. Nickel: A review of its sources and environmental toxicology. Pol J Environ Stud 15:375-382.

4. Gaillardet J, Viers J, Dupré B. 2003. Trace elements in river waters. In Drever JI, ed, Treatise on Geochemistry, Vol 5. Elsevier, New York, NY, USA, pp 225-272.

5. Centers for Disease Control and Prevention and Agency for Toxic Substances and Disease Registry. 2005. Toxicological profile for nickel: 6. Potential for human exposure. Atlanta, GA, USA.

6. U.S. Environmental Protection Agency. 2004. National recommended water quality criteria table. EPA-822-F- 04-010. Office of Water, Washington, DC

7. Lin JG, Chen SY, Su CR. 2003. Assessment of sediment toxicity by metal speciation in different particle-size fractions of river sediment. Water $S c i$ Technol 47:233-241.
8. Doig LE, Liber K. 2007. Nickel speciation in the presence of different sources and fractions of dissolved organic matter. Ecotoxicol Environ Saf 66:169-177.

9. Glover CN, Wood CM. 2005. The disruption of Daphnia magna sodium metabolism by humic substances: Mechanism of action and effect of humic substance source. Physiol Biochem Zool 78:1005-1016.

10. Meyer JS, Clearwater SJ, Doser TA, Rogaczewski MJ, Hansen JA, eds., 2007. Effects of Water Chemistry on the Bioavailability and Toxicity of Waterborne Cadmium, Copper, Nickel, Lead, and Zinc to Freshwater Organisms. SETAC, Pensacola, FL, USA.

11. Deleebeeck NME, De Schamphelaere KAC, Janssen CR. 2007. A bioavailability model predicting the toxicity of nickel to rainbow trout (Oncorhynchus mykiss) and fathead minnow (Pimephales promelas) in synthetic and natural waters. Ecotoxicol Environ Saf 67:1-13.

12. Deleebeeck NME, De Schamphelaere KAC, Janssen CR. 2008. A novel method for predicting chronic nickel bioavailability and toxicity to Daphnia magna in artificial and natural waters. Environ Toxicol Chem 27:2097-2107.

13. Deleebeeck NME, De Schamphelaere KAC, Janssen CR. 2009. Effects of $\mathrm{Mg}^{2+}$ and $\mathrm{H}^{+}$on the toxicity of $\mathrm{Ni}^{2+}$ to the unicellular green alga Pseudokirchneriella subcapitata: Model development and validation with surface waters. Sci Total Environ 407:1901-1914.

14. Kozlova T, Wood CM, McGeer JC. 2009. The effect of water chemistry on the acute toxicity of nickel to the cladoceran Daphnia pulex and the development of a biotic ligand model. Aquat Toxicol 91:221-228.

15. Worms IAM, Wilkinson KJ. 2007. Ni uptake by a green alga. 2 Validation of equilibrium models for competition effects. Environ Sci Technol 41:4264-4270.

16. Wu KB, Paquin PR, Navab V, Mathew R, Santore RC, Di Toro DM. 2003. Development of a biotic ligand model for nickel: Phase I. Water Environment Research Foundation, Report 01-ECO-10T. Water Environment Research Foundation, Alexandria, VA, USA.

17. Hammerschmidt $\mathrm{CR}$, Fitzgerald WF, Lamborg $\mathrm{CH}$, Balcom $\mathrm{PH}$ Visscher PT. 2004. Biogeochemistry of methylmercury in sediments of Long Island Sound. Mar Chem 90:31-52.

18. Weltens R, Goossens R, Van Puymbroeck S. 2000. Ecotoxicity of contaminated suspended solids for filter feeders (Daphnia magna). Arch Environ Contam Toxicol 39:315-323.

19. Degryse F, Smolders E, Parker D. 2006. White paper: The solid-liquid distribution coefficient $\left(\mathrm{K}_{\mathrm{d}}\right)$ of metals in soils. Final report to the Expanded Technical Assistance Program sponsors CDI, ICA, ICDA, ICMM, ILZRO, IMOA, NiPERA, U.S. Borax. Katholieke Universiteit Leuven, Belgium.

20. Tessier A, Campbell PGC, Bisson M. 1979. Sequential extraction procedure for the speciation of particulate trace metals. Anal Chem $51: 844-851$.

21. Allison JD, Allison TL. 2005. Partition coefficients for metals in surface water, soil, and waste. EPA/600/R-05/074. U.S. Environmental Protection Agency, Ecosystems Research Division, Athens, GA, USA.

22. Waters TF. 1995. Sediment in Streams: Sources, Biological Effects, and Control. American Fisheries Society, Bethesda, MD, USA.

23. Kördel W, Dassenakis M, Lintelmann J, Padberg S. 1997. The importance of natural organic material for environmental processes in waters and soils (Technical Report). Pure Appl Chem 69:1571-1600.

24. Glover CN, Playle RC, Wood CM. 2005. Heterogeneity of natural organic matter amelioration of silver toxicity to Daphnia magna: Effect of source and equilibration time. Environ Toxicol Chem 24:2934-2940.

25. Town RM, Filella M. 2000. A comprehensive systematic compilation of complexation parameters reported for trace metals in natural waters. Aquat Sci 62:252-295.

26. Abollino O, Giacomino A, Malandrino M, Mentasti E. 2008. Interaction of metal ions with montmorillonite and vermiculite. Appl Clay Sci 38:227-236.

27. Di Toro DM, Allen HE, Bergman HL, Meyer JS, Paquin PR, Santore RC 2001. Biotic ligand model of the acute toxicity of metals. 1. Technical basis. Environ Toxicol Chem 20:2383-2396.

28. U.S. Environmental Protection Agency. 2000. Methods for measuring the toxicity and bioaccumulation of sediment-associated contaminants with freshwater invertebrates: EPA Manual. EPA600/R-99/064. Office of Research and Development, Duluth, MN, USA.

29. U.S. Environmental Protection Agency. 2001. Methods for collection, storage and manipulation of sediments for chemical and toxicological analyses: Technical Manual. EPA-823-B- 01-002. Office of Water, Washington, DC, USA.

30. Bergaya F, Theng BKG, Lagaly G, eds. 2006. Handbook of Clay Science Elsevier, Amsterdam, The Netherlands. 
31. Smith ME, Lazorchak JM, Herrin LE, Brewer-Swartz S, Thoeny WT. 1997. A reformulated, reconstituted water for testing the freshwater amphipod, Hyalella azteca. Environ Toxicol Chem 16:1229-1233.

32. Chappie DJ, Burton GA Jr. 1997. Optimization of in situ bioassays with Hyalella azteca and Chironomus tentans. Environ Toxicol Chem 16:559-564.

33. Spitzy A, Leenheer J. 1991. Dissolved organic carbon in rivers. In Degens ET, Kempe S, Richey JE, eds, Biogeochemistry of Major World Rivers. SCOPE 42. Vol 42. John Wiley \& Sons, New York, NY, USA, pp 213-232.

34. Wehr JD, Lonergan SP, Thorp JH. 1997. Concentrations and controls of dissolved organic matter in a constricted-channel region of the Ohio River. Biogeochemistry 38:41-65.

35. Clesceri LS, Greenberg AE, Eaton AD, eds. 1998. Standard Methods for the Examination of Water and Wastewater. American Public Health Association, American Water Works Association, Water Environment Federation, Baltimore, MD, USA.

36. U.S. Environmental Protection Agency. 2007. Method 6020A: Inductively coupled plasma-mass spectrometry. Washington, DC, USA.

37. U.S. Environmental Protection Agency. 2007. Method 7000B: Flame atomic absorption spectrophotometry. Washington, DC.

38. U.S. Environmental Protection Agency. 1996. Method 3050: Acid digestion of sediments, sludges, and soils. Washington, DC.

39. U.S. Environmental Protection Agency. 2004. Method 9060A: Total organic carbon. Washington, DC.

40. Kettler TA, Doran JW, Gilbert TL. 2001. Simplified method for soil particle-size determination to accompany soil-quality analyses. Soil Sci Soc Am J 65:849-852.
41. Ludwig W, Probst J-L. 1998. River sediment discharge to the oceans: Present-day controls and global budgets. Am J Sci 298:265-295.

42. Robinson SE, Capper NA, Klaine SJ. 2009. The effects of continuous and pulsed exposures of suspended clay on the survival, growth, and reproduction of Daphnia magna. Environ Toxicol Chem 29:168175.

43. Campbell PGC. 1995. Interactions between trace metals and aquatic organisms: A critique of the free-ion activity model. In Tessier A, Turner DR, eds, Metal Speciation and Bioavailability in Aquatic Systems. Vol 3. John Wiley \& Sons, New York, NY, USA, pp 45-102.

44. Arias M, Barral MT, Mejuto JC, Rubinos D, Silva-Carvalhal J. 2004. Interaction of $\mathrm{Hg}(\mathrm{II})$ with kaolin-humic acid complexes. Clay Miner 39:35-45.

45. Jackson BP, Ranville JF, Bertsch PM, Sowder AG. 2005. Characterization of colloidal and humic-bound $\mathrm{Ni}$ and $\mathrm{U}$ in the "dissolved" fraction of contaminated sediment extracts. Environ Sci Technol 39: 2478-2485.

46. Gupta SS, Bhattacharyya KG. 2006. Adsorption of Ni(II) on clays. J Colloid Interf Sci 295:21-32.

47. Bhattacharyya KG, Gupta SS. 2008. Adsorption of a few heavy metals on natural and modified kaolinite and montmorillonite: A review. Advances Colloid Interf Sci 140:114-131.

48. Bhattacharyya KG, Gupta SS. 2008. Kaolinite and montmorillonite as adsorbents for $\mathrm{Fe}(\mathrm{III}), \mathrm{Co}(\mathrm{II})$ and $\mathrm{Ni}(\mathrm{II})$ in aqueous medium. Appl Clay Sci 41:1-9.

49. Liu A, Gonzalez RD. 1999. Adsorption/desorption in a system consisting of humic acid, heavy metals, and clay minerals. J Colloid Interf Sci 218:225-232. 